\title{
História e cultura brasileira: \\ a consolidação das Histórias em \\ Quadrinhos nos estudos da \\ Comunicação
}

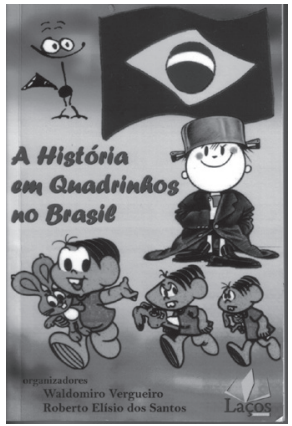

Celbi Pegoraro*

VERGUEIRO, Waldomiro; SANTOS, Roberto Elísio dos (Orgs). A história em quadrinhos no Brasil: análise, evolução e mercado. São Paulo: Editora Laços, 2011. 272 p.

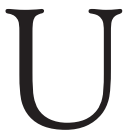

T dos temas em ascensão no âmbito acadêmico, na área de Comunicação ou de forma interdisciplinar, as Histórias em Quadrinhos têm sido foco de inúmeras pesquisas na última década. Ressalte-se que, apenas na década de 2000, a Universidade de São Paulo registrou o dobro do número de dissertações e teses sobre o assunto em comparação ao período somado das décadas de 1970 e 1990. Um dos maiores incentivos da pesquisa sobre o tema é o Observatório de Histórias em Quadrinhos, criado em 1990, na Escola de Comunicações e Artes da USP. Dentre seus objetivos estão não apenas os estudos sobre a linguagem gráfica em todos os aspectos, mas o incentivo à valorização dessa manifestação cultural e a pesquisa sem restrições, seja como fenômeno da cultura da massa, seja como produção artística.

* Jornalista e doutorando em Ciências da Comunicação no Programa de Pós- Graduação da Escola de Comunicação e Artes na Univeridade de São Paulo (USP). São Paulo-SP, Brasil. Bolsista FAPESP. E-mail: celbipegoraro@usp.br 
O livro "A História em Quadrinhos no Brasil: Análise, Evolução e Mercado", organizado pelos professores Waldomiro Vergueiro (USP) e Roberto Elísio dos Santos (USCS) - membros do Observatório -, traz importantes contribuições para o registro e análise das Histórias em Quadrinhos brasileiras. Trata-se de uma continuidade aos trabalhos teóricos sobre a produção no Brasil realizados em 2004 a pedido da "Revista Latinoamericana de Estúdios de La Historieta", publicada pela Editorial Pablo de La Torriente e lançada na Bienal del Libro de La Habana, em Cuba, em fevereiro de 2005. Os pesquisadores brasileiros desenvolveram uma série de artigos sobre a produção da arte sequencial e seus mais diversos aspectos.

O capítulo de abertura apresenta um panorama da evolução do mercado editorial de quadrinhos no Brasil. Nele, Vergueiro analisa o desenvolvimento e as tendências de mercado descrevendo não apenas os gêneros explorados pelos autores nacionais, mas também quais as principais publicações e autores nacionais e suas peculiaridades dado o contexto histórico. O leitor tem acesso a um panorama histórico desde a influência do italiano Angelo Agostini, o lançamento da primeira revista em quadrinhos nacional "O Tico-Tico", e a entrada de novos personagens na cultura brasileira, não esquecendo da importância da introdução e desenvolvimento do modelo importado dos EUA em nosso mercado. Há também uma descrição básica, porém fundamental, das principais editoras.

Vergueiro também contribui com o texto "Os super-heróis brasileiros", no qual apresenta personagens nacionais criados com forte influência de seus correlatos norte-americanos, que predominavam no mercado brasileiro.

Sonia Bibe Luyten escreve um artigo sobre o segmento dos quadrinhos certamente mais popular no Brasil, o mangá. A análise da evolução e expansão dos quadrinhos japoneses no Brasil e em relação ao mundo, além da própria exportação de bens culturais do Japão, ainda carece de maior atenção acadêmica. A autora descreve importantes aspectos históricos e os diferentes gêneros dos mangás, além de destacar a questão da forte segmentação e da relevância das mulheres como autoras dos quadrinhos.

Partindo para uma análise cultural dos quadrinhos quanto 
ao gênero, Roberto Elísio dos Santos contribui com dois artigos que complementam os textos de Vergueiro. Em "Horror e cultura brasileira: a trajetória do quadrinho de terror no Brasil”, é possível compreender como o cinema de horror hollywoodiano com monstros como Drácula, Lobisomem e Frankenstein dos anos 1930, contribuiu para a formação de um novo gênero nos quadrinhos - e sua posterior consolidação na década de 1950 que, anos mais tarde, incorporou o repertório cultural como o folclore nacional e o erotismo. Aliás, este último é justamente o tema do outro artigo de Santos no livro, no qual o autor analisa o humor, a crítica e o erotismo nos quadrinhos dos anos 1980 e 1990 a partir de publicações como o jornal Pasquim (Henfil, Jaguar, Ziraldo), tiras de jornais de Angeli, Glauco e Laerte, e ainda revistas da Circo Editorial, num novo movimento cultural que abarcou a expoente produção alternativa influenciada pelo underground comics norte-americano e o quadrinho autoral europeu.

A obra apresenta também artigos com um viés de análise histórica em gêneros e temas ainda mais específicos. É o caso de Alexandre Barbosa, que analisa a conceituação e o desenvolvimento do quadrinho histórico, representando um elo entre a documentação histórica oficial, o ensino e o entretenimento. Já Gazy Andraus investiga a situação histórico-social dos fanzines no Brasil. $O$ autor desenvolve a evolução do fanzine, além de distingui-lo de outras publicações alternativas, identificando o fanzine como um veículo impresso, muitas vezes de caráter contestatório e de expressão libertária artística que se configura como parte integrante do fim do século 20.

Completam o livro, artigos que abordam produções nacionais. Eloar Guazelli escreve uma preciosa análise da produção de quadrinhos no Rio Grande do Sul. Lucimar Mutarelli e Vergueiro apresentam artigo sobre Lourenço Mutarelli e a produção de graphic novels no Brasil, e o que isso representa para o mercado atual de quadrinhos. A questão dos diferentes gêneros se tornou fonte de inesgotáveis discussões sobre a complexidade narrativa dos quadrinhos, seja do ponto de vista de produção ou de venda, tendo em vista seus diferentes públicos leitores e seu impacto no mercado. Esta talvez seja a maior contribuição da obra. 